\title{
Cost analysis of antipsychotic drugs available in India
}

\author{
Ajay Kumar Shukla ${ }^{1 *}$, Astha Agnihotri ${ }^{2}$
}

${ }^{1}$ Department of Pharmacology, Gandhi Medical College, Bhopal, Madhya Pradesh, India ${ }^{2}$ Private Practitioner, Cupid Multispecialty Clinic, Jawahar Chowk, Bhopal, Madhya

Pradesh, India

Received: 27 December 2016 Accepted: 30 January 2017

\section{*Correspondence to:}

Dr. Ajay Kumar Shukla, Email: drajay1024@gmail.com

Copyright: (C) the author(s), publisher and licensee Medip Academy. This is an openaccess article distributed under the terms of the Creative Commons Attribution NonCommercial License, which permits unrestricted noncommercial use, distribution, and reproduction in any medium, provided the original work is properly cited.

\begin{abstract}
Background: Indian drug market has large numbers of branded formulations for every drug molecule. 1 Cost-sensitive healthcare environment has created a challenging workplace for clinicians. Efficient use of healthcare resources without compromising quality of patient care has been a challenging task for healthcare professionals. There is a wide range of variation in the prices of drugs marketed in India. Thus, a study was planned to analyse out cost variations of antiepileptic drugs available in Indian market.
\end{abstract}

Methods: Minimum and maximum costs in Rupees (INR) of different brands of same generic antipsychotic drugs, in the same strength and dosage forms were compared. The cost ratio and percentage cost variation were calculated for each generic antipsychotic drug. The number of formulations for antipsychotic drugs and number of brands for each of them were also taken into consideration.

Results: This study shows that in Indian market, there are wide variations in the prices of different brands of same generic antipsychotic drug. The highest cost ratio and percent cost variation was found for risperidone $2 \mathrm{mg}$ [(1:16.27) and 1527.48], followed by risperidone $4 \mathrm{mg}$ [(1:16.25) and 1525.25], risperidone 3 $\mathrm{mg}[(1: 15.67)$ and 1467.33], risperidone $1 \mathrm{mg}[(1: 14.86)$ and 1386.78], olanzapine $10 \mathrm{mg}$ [(1:12.36) and 1136.84], and olanzapine $5 \mathrm{mg}$ [(1:12.31) and 1130.76]. Highest number of brands of antipsychotic drug available in Indian market are for divalproex sodium $500 \mathrm{mg}(25)$ followed by olanzapine 15 $\mathrm{mg}(23)$, olanzapine $5 \mathrm{mg}(23)$, olanzapine $2.5 \mathrm{mg}(14)$, and risperidone $1 \mathrm{mg}$ (14). Highest numbers of formulations of antipsychotic drug available in Indian market are for olanzapine(06), quetiapine(05), haloperidol(05), and aripiprazole(05).

Conclusions: In Indian market, the average percentage price variation of different brands of the same oral antipsychotic drugs is very wide. Treatment with antipsychotic drugs usually has a long course with treatment adherence being a crucial factor for successful treatment. Improved adherence to the drug treatment can be ensured by decreasing the cost of therapy. Decreased drug cost expenditure can be ensured by changes in the government policies and regulations, integrating pharmacoeconomics as part of medical education curriculum, and creating awareness among treating physicians for switching to cost effective therapy.

Keywords: Adherence, Cost analysis, Compliance, Cost variation, Health Economics

\section{INTRODUCTION}

Indian drug market has large numbers of branded formulations for every drug molecule. ${ }^{1}$ Cost-sensitive healthcare environment has created a challenging workplace for clinicians. Efficient use of healthcare resources without compromising quality of patient care has been a challenging task for healthcare professionals. ${ }^{2}$
Rising medical care costs is a matter of concern for patients as well as for policy makers and service providers. Every year over 100 million people are dragged into poverty due to cost of illness and medical bills. In some countries, every year $5 \%$ of the population is forced into poverty as they have pay for health services. While millions of people suffer and die due to lack of access or inability to afford medical care, many others have to suffer as they end up paying through 
borrowing debts and selling assets etc. WHO s' annual World Health Report 2010 reflects that health and medical service is a limited resource for an unlimited demand. According to the report, between $20 \%-40 \%$ of all health expenditures are wasted because of inefficiency. Overpaying is a type of waste. In some countries, costs of medicine are up to 67 times higher than the international average price. This over expenditure grossly affects expenditures for other health services. Every year, direct and indirect medical costs have been dragging millions of Indian population into poverty. $^{3}$

In India more than $80 \%$ health financing is borne by patients. ${ }^{4}$ There has been a lack of appreciation among clinicians about the difference between inexpensive and expensive drugs. Due to their ignorance about the drug cost, they also have tendency to overestimate the cost of inexpensive drugs while underestimating the cost of expensive ones. This lack of concern ultimately results in increased overall healthcare expenditures. ${ }^{5}$

The term "psychosis" denotes a variety of mental disorders: the presence of delusions, various types of hallucinations, and grossly disorganized thinking in a clear sensorium. Schizophrenia is a kind of psychosis characterized by a clear sensorium with a marked thinking disturbance. Schizophrenia is found to be neurodevelopmental disorder. Schizophrenia is considered as a genetic disorder with high heritability. Antipsychotic drugs reduce psychotic symptoms in schizophrenia, psychotic depression, bipolar disorder, senile psychoses, drug-induced psychoses and various organic psychoses. Antipsychotic drugs have led to drastic improvement in disease management. ${ }^{6}$

Relative risk of extrapyramidal side effects (EPS) with first generation antipsychotics (FGAs) has to be evaluated against the risk of metabolic side effects of second generation antipsychotics (SGAs). ${ }^{7}$ Long-acting injectable antipsychotics should be considered, if lack of adherence contributes to inadequate clinical improvement. ${ }^{8-10}$

For the first 7 days of initial treatment, goals are decreased agitation, anxiety, tension, hostility and aggression and normalization of sleep and eating patterns. Psychotic patients in first episode, due to increased sensitivity to side effects have typical dosing ranges approximately $50 \%$ of the doses used in chronically ill individuals. $^{11}$ If there is no improvement after 3 to 4 weeks at therapeutic doses, change of antipsychotic should be considered. ${ }^{11,12}$ Improvement is slow and steady and usually takes over 6 to 12 weeks or longer. During initial 2 to 3 weeks, goals are increased socialization and improvement in self-care habits and mood. Over 6 to 8 weeks of treatment, improvement in formal thought disorder takes over. Patients early in the course of their illness experience more rapid resolution than chronically ill patients. ${ }^{7}$ Treatment has to be continued for at least 12 months after remission of first psychotic episode in a schizophrenic patient. ${ }^{8,13}$

This study was aimed at investigating and comparing the cost differences in various brands of the same generic antipsychotic agent, so that we can analyze their number of brands for each formulation and their cost variations. This appreciation of cost variation of antipsychotic drugs can be applied for more economical treatment regimen to improve the patient compliance, decreasing the rate of failure of therapy while ensuring quality patient care.

\section{METHODS}

The prices of 14 oral antipsychotic drugs, available in 49 different formulations were analyzed.

1. Cost of a particular drug (cost per 10 tablets), in the same strength and dosage forms, manufactured by different companies was obtained from "Current Index of Medical Specialties" (CIMS) April-July 2016.

2. The drugs being manufactured by only one company were excluded.

3. The cost ratio, the ratio of the cost of the costliest to cheapest brand of the same generic antipsychotic drug was calculated. From this we can deduce that how many times costliest brand costs more than the cheapest brand in each generic group.

4. Percentage cost variation was calculated as follows: ${ }^{14}$

$$
\text { Cost variation }(\%)=\frac{\text { Max. cost }- \text { Min. Cost } \times 100}{\text { Min. cost }}
$$

\section{RESULTS}

This study shows that in Indian market, there are wide variations in the prices of different brands of same generic antipsychotic drug. The highest cost ratio and percent cost variation was found for risperidone $2 \mathrm{mg}$ [(1:16.27) and 1527.48], followed by risperidone $4 \mathrm{mg}$ [(1:16.25) and 1525.25], risperidone $3 \mathrm{mg}$ [(1:15.67) and 1467.33], risperidone $1 \mathrm{mg}$ [(1:14.86) and 1386.78], olanzapine $10 \mathrm{mg}[(1: 12.36)$ and 1136.84], and olanzapine $5 \mathrm{mg}$ [(1:12.31) and 1130.76] (Table 1).

Highest number of brands of antipsychotic drug available in Indian market are for divalproex sodium $500 \mathrm{mg}(25)$ followed by olanzapine $15 \mathrm{mg}(23)$, olanzapine $5 \mathrm{mg}(23)$, olanzapine $2.5 \mathrm{mg}(14)$, and risperidone $1 \mathrm{mg}$ (14). Highest numbers of formulations of antipsychotic drug available in Indian market are for olanzapine(06), quetiapine(05), haloperidol(05), and aripiprazole(05) (Table 2).

\section{DISCUSSION}

In our study, we found that in Indian market, there are wide variations in the prices of different brands of same 
generic antipsychotic drug. The highest cost ratio and percent cost variation was found for risperidone $2 \mathrm{mg}$, followed by risperidone $4 \mathrm{mg}$, risperidone $3 \mathrm{mg}$, risperidone $1 \mathrm{mg}$, olanzapine $10 \mathrm{mg}$, and olanzapine $5 \mathrm{mg}$ (Table 1).

Table 1: Variation in cost of antipsychotic drugs.

\begin{tabular}{|c|c|c|c|c|c|}
\hline Antipsychotic Drug & Strength (mg) & Min. cost (INR) & Max. cost(INR) & Cost ratio & $\%$ cost variation \\
\hline \multirow{4}{*}{ Amisulpiride } & $50 \mathrm{mg}$ & 45.00 & 55.00 & 1.22 & 22.22 \\
\hline & $100 \mathrm{mg}$ & 75.00 & 89.00 & 1.19 & 18.66 \\
\hline & $200 \mathrm{mg}$ & 147.60 & 165.00 & 1.12 & 11.79 \\
\hline & $300 \mathrm{mg}$ & 207.00 & 235.00 & 1.13 & 13.52 \\
\hline \multirow{5}{*}{ Aripiprazole } & $5 \mathrm{mg}$ & 36.00 & 45.00 & 1.25 & 25 \\
\hline & $10 \mathrm{mg}$ & 56.00 & 80.00 & 1.43 & 42.85 \\
\hline & $15 \mathrm{mg}$ & 80.00 & 110.00 & 1.38 & 37.5 \\
\hline & $20 \mathrm{mg}$ & 99.00 & 134.00 & 1.35 & 35.35 \\
\hline & $30 \mathrm{mg}$ & 97.10 & 177.35 & 1.83 & 82.64 \\
\hline \multirow{2}{*}{ Chlorpromazine } & $50 \mathrm{mg}$ & 3.65 & 8.54 & 2.34 & 133.9 \\
\hline & $100 \mathrm{mg}$ & 5.86 & 11.63 & 1.98 & 98.46 \\
\hline \multirow{3}{*}{ Clozapine } & $25 \mathrm{mg}$ & 18.00 & 25.00 & 1.39 & 38.88 \\
\hline & $50 \mathrm{mg}$ & 35.00 & 53.00 & 1.51 & 51.42 \\
\hline & $100 \mathrm{mg}$ & 60.00 & 82.00 & 1.37 & 36.66 \\
\hline \multirow{5}{*}{ Divalproex Sodium } & 200 & 29.50 & 41.50 & 1.40 & 40.7 \\
\hline & 250 & 32 & 84 & 2.62 & 162.5 \\
\hline & 300 & 27.3 & 62.5 & 2.29 & 128.9 \\
\hline & 500 & 60 & 190 & 3.17 & 216.7 \\
\hline & 750 & 90.00 & 105.00 & 1.17 & 16.6 \\
\hline \multirow{2}{*}{ Flupentixol } & $0.5 \mathrm{mg}$ & 20.25 & 40.00 & 1.97 & 97.53 \\
\hline & $1 \mathrm{mg}$ & 35.00 & 55.00 & 1.57 & 57.14 \\
\hline \multirow{5}{*}{ Haloperidol } & $0.25 \mathrm{mg}$ & 1.96 & 15.00 & 7.65 & 665.3 \\
\hline & $1.5 \mathrm{mg}$ & 4.10 & 17.00 & 4.14 & 314.6 \\
\hline & $5 \mathrm{mg}$ & 9.25 & 32.50 & 3.51 & 251.35 \\
\hline & $10 \mathrm{mg}$ & 22.50 & 41.00 & 1.82 & 82.22 \\
\hline & $20 \mathrm{mg}$ & 45.90 & 59.41 & 1.29 & 29.43 \\
\hline \multirow{3}{*}{ Lamotrigine } & $25 \mathrm{mg}$ & 20.00 & 50.00 & 2.5 & 150 \\
\hline & $50 \mathrm{mg}$ & 37.50 & 90.00 & 2.4 & 140 \\
\hline & $100 \mathrm{mg}$ & 66.25 & 157.00 & 2.37 & 136.98 \\
\hline \multirow{2}{*}{ Loxapine } & $10 \mathrm{mg}$ & 13.33 & 34.12 & 2.56 & 155.96 \\
\hline & $25 \mathrm{mg}$ & 26.66 & 70.61 & 2.65 & 164.85 \\
\hline \multirow{6}{*}{ Olanzapine } & $2.5 \mathrm{mg}$ & 11.00 & 25.00 & 2.27 & 127.27 \\
\hline & $5 \mathrm{mg}$ & 19.50 & 240.00 & 12.31 & 1130.76 \\
\hline & $7.5 \mathrm{mg}$ & 28.00 & 46.00 & 1.64 & 64.28 \\
\hline & $10 \mathrm{mg}$ & 38.00 & 470.00 & 12.36 & 1136.84 \\
\hline & $15 \mathrm{mg}$ & 60.00 & 88.00 & 1.47 & 46.66 \\
\hline & $20 \mathrm{mg}$ & 84.00 & 144.30 & 1.71 & 71.78 \\
\hline Pimozide & $4 \mathrm{mg}$ & 48.15 & 72.75 & 1.51 & 51.09 \\
\hline \multirow{5}{*}{ Quetiapine } & $25 \mathrm{mg}$ & 16.00 & 28.00 & 1.75 & 75 \\
\hline & $50 \mathrm{mg}$ & 25.00 & 45.00 & 1.8 & 80 \\
\hline & $100 \mathrm{mg}$ & 40.00 & 60.00 & 1.5 & 50 \\
\hline & $200 \mathrm{mg}$ & 78.00 & 104.00 & 1.33 & 33.33 \\
\hline & $300 \mathrm{mg}$ & 110.00 & 149.00 & 1.35 & 35.45 \\
\hline \multirow{4}{*}{ Risperidone } & $1 \mathrm{mg}$ & 9.08 & 135.00 & 14.86 & 1386.78 \\
\hline & $2 \mathrm{mg}$ & 16.59 & 270.00 & 16.27 & 1527.48 \\
\hline & $3 \mathrm{mg}$ & 25.84 & 405.00 & 15.67 & 1467.33 \\
\hline & $4 \mathrm{mg}$ & 33.22 & 540.00 & 16.25 & 1525.25 \\
\hline \multirow{2}{*}{ Valproic Acid } & $200 \mathrm{mg}$ & 22.53 & 46.00 & 2.04 & 104.1 \\
\hline & $500 \mathrm{mg}$ & 47.00 & 97.50 & 2.07 & 107.4 \\
\hline
\end{tabular}


Table 2: Brands and formulations of antipsychotic drugs.

\begin{tabular}{|c|c|c|c|}
\hline $\begin{array}{l}\text { Antipsychotic } \\
\text { drug }\end{array}$ & Formulations & $\begin{array}{l}\text { Strength } \\
\text { (mg) }\end{array}$ & Brands \\
\hline \multirow{4}{*}{ Amisulpiride } & \multirow{4}{*}{04} & $50 \mathrm{mg}$ & 10 \\
\hline & & $100 \mathrm{mg}$ & 11 \\
\hline & & $200 \mathrm{mg}$ & 04 \\
\hline & & $300 \mathrm{mg}$ & 04 \\
\hline \multirow{5}{*}{ Aripiprazole } & \multirow{5}{*}{05} & $5 \mathrm{mg}$ & 03 \\
\hline & & $10 \mathrm{mg}$ & 11 \\
\hline & & $15 \mathrm{mg}$ & 11 \\
\hline & & $20 \mathrm{mg}$ & 08 \\
\hline & & $30 \mathrm{mg}$ & 10 \\
\hline \multirow{2}{*}{ Chlorpromazine } & \multirow{2}{*}{02} & $50 \mathrm{mg}$ & 02 \\
\hline & & $100 \mathrm{mg}$ & 02 \\
\hline \multirow{3}{*}{ Clozapine } & \multirow{3}{*}{03} & $25 \mathrm{mg}$ & 05 \\
\hline & & $50 \mathrm{mg}$ & 04 \\
\hline & & $100 \mathrm{mg}$ & 06 \\
\hline \multirow{5}{*}{$\begin{array}{l}\text { Divalproex } \\
\text { Sodium }\end{array}$} & \multirow{5}{*}{05} & $200 \mathrm{mg}$ & 10 \\
\hline & & $250 \mathrm{mg}$ & 11 \\
\hline & & $300 \mathrm{mg}$ & 10 \\
\hline & & $500 \mathrm{mg}$ & 25 \\
\hline & & $750 \mathrm{mg}$ & 07 \\
\hline \multirow{2}{*}{ Flupentixol } & \multirow{2}{*}{02} & $0.5 \mathrm{mg}$ & 04 \\
\hline & & $1 \mathrm{mg}$ & 03 \\
\hline \multirow{5}{*}{ Haloperidol } & \multirow{5}{*}{05} & $0.25 \mathrm{mg}$ & 05 \\
\hline & & $1.5 \mathrm{mg}$ & 06 \\
\hline & & $5 \mathrm{mg}$ & 07 \\
\hline & & $10 \mathrm{mg}$ & 05 \\
\hline & & $20 \mathrm{mg}$ & 02 \\
\hline \multirow{3}{*}{ Lamotrigine } & \multirow{3}{*}{03} & $25 \mathrm{mg}$ & 04 \\
\hline & & $50 \mathrm{mg}$ & 04 \\
\hline & & $100 \mathrm{mg}$ & 04 \\
\hline \multirow{2}{*}{ Loxapine } & \multirow{2}{*}{02} & $10 \mathrm{mg}$ & 02 \\
\hline & & $25 \mathrm{mg}$ & 02 \\
\hline \multirow{6}{*}{ Olanzapine } & \multirow{6}{*}{06} & $2.5 \mathrm{mg}$ & 14 \\
\hline & & $5 \mathrm{mg}$ & 23 \\
\hline & & $7.5 \mathrm{mg}$ & 10 \\
\hline & & $15 \mathrm{mg}$ & 23 \\
\hline & & $10 \mathrm{mg}$ & 07 \\
\hline & & $20 \mathrm{mg}$ & 04 \\
\hline Pimozide & 01 & $4 \mathrm{mg}$ & 02 \\
\hline \multirow{5}{*}{ Quetiapine } & \multirow{5}{*}{05} & $25 \mathrm{mg}$ & 08 \\
\hline & & $50 \mathrm{mg}$ & 09 \\
\hline & & $100 \mathrm{mg}$ & 10 \\
\hline & & $200 \mathrm{mg}$ & 10 \\
\hline & & $300 \mathrm{mg}$ & 05 \\
\hline & & $1 \mathrm{mg}$ & 14 \\
\hline Pisneridone & 04 & $2 \mathrm{mg}$ & 13 \\
\hline Kisperidone & 04 & $3 \mathrm{mg}$ & 10 \\
\hline & & $4 \mathrm{mg}$ & 11 \\
\hline Volnrois A cid & & $200 \mathrm{mg}$ & 09 \\
\hline Valproic Acid & UL & $500 \mathrm{mg}$ & 08 \\
\hline
\end{tabular}

Highest number of brands of antipsychotic drug available in Indian market are for divalproex sodium 500mg followed by olanzapine $15 \mathrm{mg}$, olanzapine $5 \mathrm{mg}$, olanzapine $2.5 \mathrm{mg}$, and risperidone $1 \mathrm{mg}$. Highest numbers of formulations of antipsychotic drug available in Indian market are for olanzapine, quetiapine, haloperidol and aripiprazole (Table 2).

There were three antipsychotic drugs chloprpromazine, haloperidol and olanzapine included in National list of essential medicines (NLEM) 2011. ${ }^{15}$ NLEM 2015 has included four antipsychotic drugs clozapine, fluphenazine, haloperidol, and risperidone. ${ }^{16} \mathrm{We}$ can see that more number of drugs and formulations which have been included in NLEM 2015 as compared to NLEM 2011. ${ }^{15,16}$ Thus, cost of more number of antipsychotic drugs will be regulated by drug prices control order (DPCO) 2013. ${ }^{17}$ This will play an important role in reducing the cost variation among the most commonly used antipsychotic drugs.

As per the recommendations of many experts, in schizophrenia patients with robust treatment response, medications should be continued for at least a period of 5 years. To prevent relapse in majority of chronic cases of schizophrenia, lifetime pharmacotherapy is recommended. Treatment should be started with lowest effective dose of antipsychotic medication that is most likely tolerated by the patient. ${ }^{8,13}$

Higher medication costs play an important role for medication nonadherence. ${ }^{18}$ Cost related poor medication adherence has been associated with adverse health outcomes. $^{19}$

In individuals with chronic illnesses it is often a challenge to maintain medication adherence. ${ }^{20}$ Individuals with serious mental disorders has higher nonadherence rates as compared to those with general medical disorders. ${ }^{7}$

Decreased drug cost has been found to improve adherence to the medication regimen. ${ }^{21}$ Non compliance of the drug therapy results in progression of the disease which increases the overall medical care costs dramatically.

In the treatment of epilepsy, treatment with generic antiepileptic drugs was found to have fewer adverse seizure-related clinical outcomes and improved treatment adherence than treatment with brand name versions. ${ }^{22}$ The cost of medicines has been found to depend on their marketing strategies. There has been no correlation found between the quality of the medicine and its corresponding price. ${ }^{23}$ Thus, it appears crucial that large cost differences between the brands of same generic antipsychotic drug have to be regulated by concerned agencies.

There is a lack of appreciation among the prescribing doctors about the magnitude of cost variation of drugs. 
Prescribing doctors usually overestimate the cost of inexpensive drugs while underestimating the cost of expensive ones. This consequentially leads to increased overall drug expenditures. ${ }^{5}$ More than $80 \%$ health financing is borne by patients in India. ${ }^{4}$ In India, where majority of patients are paying out of their pockets for their medical bills and are not covered by insurance schemes, due importance to the costs of drug should be given by prescribing doctors. ${ }^{24}$ In Indian market, wide and variable cost variations have been found among different brands of antiepileptic drugs, antidepressant drugs and antidyslipidemic drugs. ${ }^{25-27}$

Pharmacoeconomics and its influence on healthcare expenditure should be a component of medical education curriculum. This will create awareness about the impact of cost of therapy on the medication adherence and successful treatment of the disease. Physician's awareness about the cost differences of drugs can be enforced by ensuring ready availability of drug manual which has comparative drug prices. Availability of drug manual has been associated with reduction of patients' drug expenditure. ${ }^{28}$

Currently, very few antipsychotic drugs are under drug prices control order. Government should regulate costs of more number of antipsychotic drugs. Thus, this study highlights that there exists a wide and variable price variation among the antipsychotic drugs manufactured by different companies. Strong measures must be taken by the government and concerned agencies for uniformity in drug pricing. Due consideration must be placed on antipsychotic drugs to increase their affordability and accessibility to common people.

\section{CONCLUSION}

In Indian market, the average percentage price variation of different brands of the same oral antipsychotic drugs is very wide. Treatment with antipsychotic drugs usually has a long course with treatment adherence being a crucial factor for successful treatment. Improved adherence to the drug treatment can be ensured by decreasing the cost of therapy. Decreased drug cost expenditure can be ensured by changes in the government policies and regulations, integrating pharmacoeconomics as part of medical education curriculum, and creating awareness among treating physicians for switching to cost effective therapy.

\section{Funding: No funding sources Conflict of interest: None declared \\ Ethical approval: Not required}

\section{REFERENCES}

1. Das SC, Mandal M, Mandal SC. A critical study on availability and price variation between different brands: Impact on access to medicines. Indian $\mathbf{J}$ Pharm Sci. 2007;69(1):160-3.
2. Di Piro JT, Lamber RL, Yee GC, Matzke GR, Wells BG, Posey LM. Pharmacoeconomics: Principles, Methods, and Applications. Pharmacotherapy: a Pathophysiologic Approach. 19e. New York: McGraw-Hill; 2011:01.

3. Gupta SK. Proposed Pharmacoeconomics Guidelines for India (PEG-I). IPSOR India Chapter; 2013:79100.

4. Creese A, Kotwani A, Kutzin J, Pillay A. Evacuating pharmaceuticals for health policy in low and middle income country settings. In: Freemantle N, Hill S, editors. Evaluating pharmaceuticals for health policy and reimbursement. Massachusetts, USA: Blackwell Publication; (in collaboration with WHO Geneva); 2004:227-43.

5. Shrank WH, Hoang T, Ettner SL. The implications of choice: prescribing generic or preferred pharmaceuticals improves medication adherence for chronic conditions. Arch Intern Med. 2006;166(3):332-7.

6. DeBattista C. Antipsychotic Agents and Lithium. In: Katzung BC, Trevor AJ. Basic and Clinical Pharmacology. $13^{\text {th }}$ ed. New York, NY: McGrawHill; 2015:660-8.

7. Crismon ML, Argo TR, Buckley PF. Schizophrenia. In: Di Piro JT, Lamber RL, Yee GC, Matzke GR, Wells BG, Posey LM. Pharmacotherapy: a Pathophysiologic Approach. 19e. New York, NY: McGraw-Hill; 2011:1147-69.

8. Lehman AF, Lieberman JA, Dixon LB. American Psychiatric Association Practice Guidelines; Work Group on Schizophrenia. Practice guideline for the treatment of patients with schizophrenia, $2^{\text {nd }} \mathrm{ed}$. Am J Psychiatry. 2004;161(2S):1-56.

9. Castle DJ, Buckley PF. Schizophrenia. Oxford, UK: Oxford University Press; 2008. Available from: https://www.ncbi.nlm.nih.gov/pmc/articles/PMC4159 061/

10. Buchanan RW, Kreyenbuhl J, Kelly DL. The 2009 schizophrenia PORT psychopharmacological treatment recommendations and summary statements. Schizophr Bull. 2010;36:71-93.

11. Moore TA, Buchanan RW, Buckley PF. The Texas Medication Algorithm Project antipsychotic algorithm for schizophrenia: 2006 update. J Clin Psychiatry. 2007;68:1751-62.

12. Meltzer HY. What's atypical about atypical antipsychotic drugs? Curr Opin Pharmacol. 2004;4:53-57.

13. Argo TR, Crismon ML, Miller AL. Schizophrenia Treatment Algorithms, Texas Medication Algorithm Project Procedural Manual. Austin, TX: Texas Department of State Health Services; 2008. Available from: http:// www.dshs.state.tx.us/mhprograms/TIMA.shtm.

14. Akila L, Rani RJ. Cost analysis of different brands of antianginal drugs available in India. Int $\mathrm{J}$ Basic Clin Pharmacol. 2015;4:860-3.

15. National List of Essential Medicines, 2011. Available at: 
http://www.who.int/selection_medicines/country_list s/India_NLEM_2011.pdf.Accessed on 31 July 2016.

16. National list of essential medicines 2015. Available from: http://www.drugscontrol.org/pdf/NLEM2015.pdf. Accessed on 31 July 2016.

17. Drugs (Price Control) - National Pharmaceutical Pricing Authority. Available at: www.nppaindia.nic.in/DPCO2013.pdf. Accessed on 30 July 2016.

18. Ho PM, Bryson CL, Rumsfeld JS. Medication Adherence: It's Importance in Cardiovascular Outcomes. Circulation. 2009;119:3028-35.

19. Jana S, Mondal P. Pharmacoeconomics: the need to sensitize undergraduate medical students. Indian $\mathrm{J}$. Pharmacol. 2005;37(5):277-8.

20. Lindenmayer JP, Liu-Seifert H, Kulkarni PM. Medication nonadherence and treatment outcomes in patients with schizophrenia or schizoaffective disorder with suboptimal prior response. J Clin Psychiatry. 2009;70:990-6.

21. Shrank WH, Hoang T, Ettner SL. The implications of choice: prescribing generic or preferred pharmaceuticals improves medication adherence for chronic conditions. Arch Intern Med. 2006;166(3):332-7.

22. Gagne JJ, Kesselheim AS, Choudhry NK, Polinski JM, Hutchins D, Matlin OS, et al. Comparative effectiveness of generic versus brand-name antiepileptic medications. Epilepsy Behav. 2015 Nov;52(Pt A):14-8.
23. Singal GL, Nanda A, Kotwani A. A comparative evaluation of price and quality of some branded versus branded-generic medicines of the same manufacturer in India. Indian $\mathbf{J}$ Pharmacol. 2011;43:131-6.

24. Essential medicines and health products information portal. A World Health Organization resource. Available at: http://apps.who.int/medicinedocs/en/d/Jwhozip33e/5. 3.html.Accessed 12 August 2016.

25. Shukla AK, Mehani R. Cost analysis of antiepileptic drugs available in India. Int $\mathrm{J}$ Basic Clin Pharmacol. 2016;5:1636-40.

26. Shukla AK, Sharma P. Cost variation study of antidepressant drugs. Int J Basic Clin Pharmacol. 2016;5:1816-21.

27. Shukla AK, Sharma P. Cost variation analysis of antidyslipidemic drugs. Int J Basic Clin Pharmacol. 2016;5:1850-5.

28. Frazier LM, Brown JT, Divine GW, Fleming GR, Philips NM, Siegal WC, et al. Can physician education lower the cost of prescription drugs? A prospective, controlled trial. Ann Intern Med. 1991;115(2):116-21.

Cite this article as: Shukla AK, Agnihotri A. Cost analysis of antipsychotic drugs available in India. Int J Basic Clin Pharmacol 2017;6:669-74. 